\title{
Two parts: touch to affliction
}

\section{Nathalie Stephens}

\begin{abstract}
À la fois une accusation adressée à la langue anglaise et une réflexion sur les conséquences du deuil, ce texte reformule (et déforme) la notion de patrie (homeland) et en souligne les effets dévastateurs sur l'histoire contemporaine européenne, nord-africaine et nord-américaine.
\end{abstract}

\section{My Thigh Grew A City}

I went into a new city with old words.

A river swallowed a lake. An iron bridge swerved and hooked the sky. The names of streets scattered.

Three held passion.

I bit into a wooden rail. Water rose to where I stood. A strangulated swamp and gold and granite. Books.

I carried a small body in my teeth.

Claim nothing as your own. Not curvature. Nor comfort. Nor sleep.

I wanted fracture. I wanted fleeting. I wanted feign. The city bore into bone. The wound opened onto sound. The sound echoed and echoed into the small body and cringing hands and settled on a stone step and I said nothing. "Nothing." Wept.

The lake shrank from two bodies at least. 


\section{$114 \cdot$ Tessera}

Inside memory is little worth keeping. Match sticks. Some loose change. And the frayed edges of your city. Frayed because of memory. I am trying not to touch it too often, nor imagine it too fiercely.

Inside memory is the failure of memory. I go there and come upon my arrogance at wanting the thing that language won't offer. What your language says as distinctly as mine. What is wanting. What is reach. Language does not beckon. It scoffs. Inside your city with its vengeful rivers and wrought bridges. When it says "I love" it knocks holes into the riverbed. We will drown in the city and we will take our languages with us. 
Desire is not a measure for speaking. One man leans into another man and this man catches the first in a quiet embrace. The street sounds dissipate. The smoke stacks cough rings into the city. The rail lines buckle and break.

I am that man and I am both leaning and not leaning.

The city is this city.

The train is late.

I wait for the tall light to amber. I listen to the feather weight of fall. I reach into the bone collapse of grief. And the stranger reache for me.

My eyes move from the man's mouth to the orange sky.

The city catches fire.

And we are in it. 


\section{$116 \cdot$ Tessera}

Not Paris

I want to know: What part of you remains inconsolable?

If these are letters to myself, the names beside them are thin screens of hope. Perhaps. The tear is visible.

What part of fear is not attached to a name? What part of a name does not beckon exile? What part of exile does not disavow living? 
A city's worth is a consequence of its bookshops and architecture. And its capacity to withstand suffering.

Our cities are well worn and there is beauty showing through. Their languages are sooty and they are delirious with crumbling.

On the name of each city is a layer of dust. Underneath the dust is nothing much.

Is the dust what we came for? 


\section{$118 \cdot$ Tessera}

For begins the words forgotten and forlorn. It is possible to mount a history of a place on the inconsistent edges of letters. Our history, if there is such a thing as a shared history, might slide into the crook of an " $r$ " and remain wedged there for a time.

There is little to say in answer to that.

Nonetheless I will say this: I am entering into an old alphabet with no words. I may emerge with fewer still. 
These months I have walked through three cities. Each city had its rivers for drowning and lovers stood at their edges. I was none of these lovers and in each city I touched the thing that needed breaking most.

First came the jolt of recognition. Then the shame that comes with knowing.

Out loud I spoke words of one language and then of another.

Two hands covered my mouth and a body rose from water. I reached for it and fell.

On my knees the earth was quiet and the wind blew over me.

This is what your language will not give me.

The thing that is breaking. The thing that is known. 


\section{$120 \cdot$ Tessera}

Simone Weil was dead before she was dying. When she was still Jacob.

Words came away from her tongue and her pen was insolent with knowing. She was mad.

Her body tore from its canvas. She found nothing in the thing she desired.

Le vide is not nothing.

Weil's language was a language of not meaning.

She left room for the thing that was breaking.

She slept with her head against a pile of stones. 
In Paris, the Seine overflows and corpses wash onto its shores. The tourists board the bateaux-mouches. The sky fills with buzzards. And the Levites gnash their teeth.

Le corps is not the same as corpses. And this is not Paris. But it's close enough.

Your language gives me order. It says nothing of la douleur.

I take it into my hands as I would a large stone and I drop it into water.

What wants seeing and the small body with it rises from under. 